\title{
HAPPINESS AS A FACTOR OF INDIVIDUAL HARDINESS
}

In Happiness And Contemporary Society : Conference Proceedings Volume (Lviv, March, 20-21, 2021). Lviv: SPOLOM, 2021. P. 74-76. https://doi.org/10.31108/7.2021.14

ISBN 978-966-919-697-2 


\author{
CHYKHANTSOVA Olena \\ PhD in Psychology, Senior Researcher, \\ Chamaty Laboratory of Psychology of Personality, \\ Kostiuk Institute of Psychology of NAES of Ukraine (Kyiv, Ukraine)
}

\title{
HAPPINESS AS A FACTOR OF INDIVIDUAL HARDINESS
}

Important studies for modern psychology are aimed at identifying factors that help counteract the negative influence of the environment. These factors also contribute to finding internal reserves, providing it independence of choice, self-direction and selfrealization. Thus, one of the factors that helps an individual to reduce the impact of negative environmental consequences on human life is happiness. So, happiness can be defined as subjective well-being or as the actualization of human potential.

But to understand the causes and effects of happiness, researchers first need to define it. Many of them use the term interchangeably with 'subjective well-being', which they measure by simply asking people to report how satisfied they feel with their own lives and how much positive and negative emotion they're experiencing. Positive psychology researcher S. Lyubomirsky elaborates in her book'The How of Happiness', describing happiness as 'the experience of joy, contentment, or positive well-being, combined with a sense that one's life is good, meaningful, and worthwhile' (Lyubomirsky, 2008).

Nowadays, there are two prevailing perspectives on the study of happiness. In the empirically derived hedonic view, well-being consists of pleasure or happiness. Research that stems from this perspective typically construes happiness as subjective well-being, people's emotional and cognitive evaluations of their lives as measured by their selfreported degree of global positive affect, negative affect, and overall life satisfaction. In the theoretically derived eudaemonic perspective, psychological well-being is construed as the maximization or actualization of human potential. Research that stems from this perspective generally focuses on behavior and cognitions rather than feeling.

Researchers working on the problems of human existence in difficult life situations focus on the functioning of the individual in adverse developmental conditions in order to identify personal characteristics that allow a person to achieve self-realization and psychological well-being and happiness (Maddi, 2006; Seligman \& Scikszentmihalyi, 2000). Studies have identified various predictors that mediate the hardiness of the individual: personal autonomy (Ryan \& Deci, 2017), meaningful life (Ryff \& Singer, 1998), optimism and positive mood (Mahdian \& Ghaffari, 2016); hope for the future (Najmeh, 2020) and happiness (Argyle, 2013). Analysis of the research (Kuprieieva, Traverse, Serdiuk, Chykhantsova, Shamych, 2020) conducted in the study of external and internal factors of the human ability to withstand exposure to adverse conditions, led to the conclusion that the personality predictors of individual hardiness, overcoming difficult situations include the following a resource of happiness.

Analyzing the factors that characterize the hardiness of the individual, it should be noted that the positive influence has the desire for autonomy, the desire for selfdevelopment and self-realization, self-efficacy, belief in their abilities, happiness, the 
need for achievement; volitional and organizational abilities of a person, the ability to structure their behavior, the definition of goals, meaningfulness of life and purposefulness, self-organization, the ability to control life events and a balanced assessment of their own capabilities.

In our study, we identified a direct correlation between hardiness variables and happiness. This means that the content of the results indicates that the growth of the level of hardiness is accompanied by the actualization of such a component as happiness. The ability to positively overcome adverse events allows hardiness people to adapt to significant life changes and thus function better because they are able to accept the challenge and emerge stronger, wiser and more powerful. We have also found that hardiness is highly correlated with mental health, success, satisfaction and happiness.

It is worth emphasizing that happiness is one of the important indicators in identifying people's satisfaction with life. In our study, we found that almost every third person feels happy, but every fourth is unhappy. The results of the study confirm that the higher people's quality of life according to their own assessment, the happier they feel.

It should be noted that the assessment of quality of life is relative. Determining a person's degree of satisfaction of their needs is based on their life experience, level of cultural, intellectual, emotional development. Thus, quality of life is expressed as psychological well-being, in which a person feels inner satisfaction from the conditions of his life (Chykhantsova, 2020).

Thus, hardiness is one of the key parameters of individual ability to mature and complex forms of self-determination and is based on the ability to be guided in life by their own values, freedom of choice and show inner creativity, self-understanding and self-acceptance, belief in their abilities. All this is the psychological basis of happiness and psychological well-being of the individual. So, the concept of social and psychological well-being remains relevant, which is the basis of personal happiness and has a close connection with hardiness, which is presented abroad as 'Positive Psychology'.

\section{REFERENCES}

1. Argyle, M. (2013). The Psychology of Happiness. 2nd ed. Routledge, NY.

2. Chykhantsova O. A. (2020). A person's quality of life and features of its measurement. Insight: the psychological dimensions of society, 4, 11-28. https://doi.org/10.32999/2663-970X/2020-4-1

3. Kuprieieva, O., Traverse, T., Serdiuk, L., Chykhantsova O., \& Shamych, O. (2020). Fundamental assumptions as predictors of psychological hardiness of students with disabilities. Social Welfare. Interdisciplinary Approach, 10 (1), 96-105. https://doi.org/10.21277/sw.v1i10.566

4. Lyubomirsky, S. (2008). The How of Happiness: A New Approach to Getting the Life You Want. Penguin Books.

5. Maddi, S. R. (2006). Hardiness: The courage to grow from stresses. The Journal of Positive Psychology, 1. P. 160-168. https://doi.org/10.1080/17439760600619609

6. Mahdian, Z, \& Ghaffari, M. (2016). The mediating role of psychological resilience, and social support on the relationship between spiritual well-being and hope in cancer patients. Journal of Fundamentals of Mental Health, 18. 
http://scholar.google.com/scholar?hl=en\&as_sdt=0\%2C5\&q=Mahdian+Z\%2C+Ghaf fari+M.+The+mediating+role+of +psychological\&btnG

7. Najmeh, H. (2020). Study of the Relationship of Hardiness and Hope with Life Satisfaction in Managers. International Journal of Psychology, 14, (1), Winter \& Spring, 310-339. https://doi.org/10.24200/IJPB.2020.214143.1143

8. Ryan, R. M., \& Deci, E. L. (2017). Self-determination theory: Basic psychological needs in motivation, development, and wellness. The Guilford Press. https://doi.org/10.1521/978.14625/28806

9. Ryff, C. D., \& Singer, B. (1998). The contours of positive human health. Psychological Inquiry, 9. P. 1-28.

10. Seligman, M.E.P., \& Csikszentmihalyi, M. (2000). Positive psychology. American psychologist, 55/1, 5-14. 